\title{
Az önkormányzati politika központi és lokális feltételeinek alakulása krízisidőszakokban
}

\section{SZABÓ TAMÁS ${ }^{1}$ - HORVÁTH ANETT ${ }^{2}$}

Az elmúlt több mint egy évtized során a magyarországi helyi önkormányzatok legalább két kívülrool eredő exogén jellegü krízisszituációt éltek és élnek át jelenleg is. Ezek jellegüknél fogva különbözöek: több mint egy évtizede a 2008-2009-es gazdasági és pénzügyi világválság és vele a globális világgazdaság káros turbulenciáinak való kitettség (például önkormányzati devizaadósság, beszükülö fiskális mozgástér és romló állami finanszírozás), a 2020-2021-es Covid-19-járvány okozta pandémia időszakában közvetlenül az egészségügyi veszélyhelyzet, közvetett módon pedig a gazdasági viszszaesés okozta krízisek jelentettek rendszerszintü, paradigmatikus hatású kihívást a helyhatóságok számára.

A közpolitikai változás (policy change) és közpolitikai probléma (policy problem), valamint a közpolitikai válság, krízis (policy crisis) nemzetközi szakirodalma által használatos fogalomrendszer mentén vizsgáljuk a központi (parlamenti, kormányzati) jogalkotásnak az önkormányzati szektorra gyakorolt hatásait a két krízis során. Szintetizáljuk az alkalmazott alkotmányos, közjogi eszközöket, a két válság idöszakában fennálló politikai (parlamenti, kormányzati) környezetet, valamint az önkormányzati szektor mozgásterét, lehetöségeit. Tanulmányunk fontos elemzési dimenziója, hogy a központi döntési szintnek krízisszituációban hozott döntései (például törvényalkotás, önkormányzatok állami finanszírozása, különleges jogrend során hozott kormányrendeletek) tartalmukat tekintve nemcsak a problémák feloldásának irányába mutathatnak, hanem akár új „konfliktuskonténereket" is nyithatnak ki.

Kulcsszavak: közpolitikai változás, közpolitikai válság- és krízismenedzsment, helyi önkormányzatok, különleges jogrend

\section{Central and Local Conditions of Municipal Policy in Crisis}

Over the past decade, local governments in Hungary have experienced and are currently experiencing at least two exogenous crises of external origin.

1 Adjunktus, Milton Friedman Egyetem Nemzetközi és Politikatudományi Tanszék, e-mail: szabo.tamas978@gmail.com

2 Adjunktus, Nemzeti Közszolgálati Egyetem Kormányzástani és Közpolitika Tanszék, e-mail: horvath.anett@uni-nke.hu 


\begin{abstract}
These are different in nature: for more than a decade, the 2008-2009global economic and financial crisis and its exposure to the harmful turbulences of the global economy (for example, municipal foreign currency debt; narrowing fiscal room for manoeuvre and deteriorating public finances) during a coronavirus pandemic, crises caused directly by health emergencies and, indirectly, by crises caused by the economic downturn posed a systemic, paradigmatic challenge for local authorities.

We examine the effects of central (parliamentary, governmental) legislation on the local government sector during the two crises along the lines of concepts used by the international literature on policy change and policy problem and policy crisis. An important analytical dimension of our study is that decisions made by the central decision-making level in a crisis situation (for example, legislation; local government funding; government decrees issued under a special legal order) may not only open up problems but also open new 'conflict containers.'
\end{abstract}

Keywords: public policy change, public policy crisis and crisis management, local governments, special legal order

„A változás minden tudomány alapvető tevékenysége a biológiától és a genetikától az antropológiáig és a szociológiáig bezárólag. A kérdés a következő: miért, mikor és hogyan történik a változás és mi történik egy ilyen változás során? Az ilyen

kérdések megválaszolása a tudományos kutatás területén részt vevők feladata."

Capano, $2015^{3}$

\title{
1. A közpolitikai változás, a közpolitikai kudarc és siker kettőssége, valamint a szürke zóna e kettő közt, a közpolitikai krízis
}

\subsection{A közpolitikai változás (policy change)}

Először is fontos megkülönböztetni a közpolitikai változást (policy change) a közpolitikai reformtól (policy reform). A közpolitikai változás a meglévő struktúrák elmozdulására utal, vagy új és innovatív mechanizmusok megjelenésére, ${ }^{4}$ addig a reform markáns változást takar. A közpolitikai változás (vagy annak hiánya) kérdésének

3 Giliberto Capano - Michael Howlett - M. Ramesh: Bringing Governments Back in: Governance and Governing in Comparative Policy Analysis. Journal of Comparative Policy Analysis: Research and Practice, 17. (2015), 4. 311-321. 
elemzésénél érdemes kitérni az útfüggőség ${ }^{5}$ modelljére. Ez a modell azzal érvel, hogy általában nehéz a közpolitikát megváltoztatni, mert az intézményi müködések konzerválódnak és a szereplők megvédik a meglévő modellt (még akkor is, ha az nem optimális), így a korábbi döntések ösztönzik a politika folytonosságát. Ezen elmélet legfőbb erőssége, hogy képes megmagyarázni, miért valószínűbb a közpolitika folytonossága, mint a változása. Miután egy ország elindult egy bizonyos közpolitikai úton, nehéz ezen az úton változtatni, mert a szereplők és a közpolitikák intézményesültek, amelyek megváltoztatása nagy erőfeszítéseket és költségeket igényel. Mégis, számos kiváló oka van annak, hogy a közpolitikai mechanizmusok megváltoztatása megéri a fáradságot. Általában óriási különbség mutatkozik egy-egy probléma felmerülése kapcsán annak szőnyeg alá söprése és a tényleges takarítás között, hogy ne jelenjenek meg újra. A közpolitika megváltoztatása hosszú távon könnyebb, mint ugyanazokat a csatákat újra és újra megvívni. Még ha sikerül is engedményeket elérni egy adott kérdésben, ha a döntéshozó nem változtatta meg az adott kérdésre vonatkozó közpolitikai mechanizmusát, előfordulhat, hogy újra és újra ugyanazon nehézséggel szembesül minden alkalommal, amikor az újra felmerül. A probléma vákuumban történő kezelése összehasonlítható a betegség kiváltó okainak kezelésével és a tünetek kezelésével. Ha kiküszöböli az okokat, a beteg meggyógyulhat, ha csak a tüneteket kezeli, akkor egy ideig jobban fogja érezni magát, de a betegség újra fellángolhat.

A megváltozott irányelvek megváltoztathatják az emberek gondolkodását és hozzáállását. A gyermeknevelés egyik elmélete, amely a gyakorlatban látszólag jól müködik, az az, hogy ha a gyermek elég sokáig elfogadható módon viselkedik, akkor ez a magatartás a gyermek énképének részévé válik. Más szóval, ez már nem pusztán viselkedés, hanem része annak, amit a gyermek önmagának képzel el. Ugyanez vonatkozhat egy közösségre is: ha egy kérdéssel sajátos módon foglalkoznak, az új politikák maguk is a közösség önképének részévé válnak, és hosszú távú változásokhoz vezetnek. A közpolitikai változások a tartós társadalmi változások egyik útját jelentik. A fenti okok miatt a politikák megváltoztatása valóban a társadalom megváltoztatásának egyik módja. A szóban forgó politikai változások felülről származhatnak hivatalos kormányzati döntések formájában, amelyeket törvényekké vagy rendeletekké alakítanak át. Vagy származhatnak az alapokból, szakszervezetekből, munkahelyekből és társadalmi csoportokból. Függetlenül attól, hogy ezek honnan származnak, a politikában bekövetkezett változások, amelyek a társadalmi kérdések valódi okait és az érintett emberek valós szükségleteit tükrözik, valós és tartós társadalmi változásokhoz vezetnek.

A téma kutatása egészen az 1950-es évek végére nyúlik vissza, amikor olyan tudósok, mint Herbert Simon (1957), Charles Lindblom (1959) és Thomas Kuhn (1962) azt feltételezték, hogy „a közpolitikai folyamatok nem csak azonosíthatók, hanem megjósolhatók" ${ }^{\prime \prime}$ is, emiatt a közpolitikai változások megértése és elmagyarázá-

\footnotetext{
5 Paul Pierson: Increasing Returns, Path Dependence, and the Study of Politics. American Political Review, 94. (2000), 2. 251-267.

6 Howlett (2010): i. m.
} 
sa az évek előrehaladtával egyre fontosabbá vált. „A modern államot széles körben aktívnak és proaktívnak tekintették, amely egyre inkább irányítójává, formálójává vált a társadalmi folyamatoknak."

Tehát a közpolitikai változások (policy change) jelentős hatásúak. Ezek lehetnek átfogó, strukturális jellegủek, valamint hatásukat tekintve alacsonyabb szintü, időben elhúzódó funkcionális változások. A közpolitikai változások természetét átfogóan Peter Hall írta le 1993-ban, egy háromszintű modellben felvázolva.

Elsőrendủ közpolitikai változás, amikor a kitűzött közpolitikai célok és azok fontossági sorrendje megmarad, ugyanakkor az alkalmazott eszközöket (jogi természetü, anyagi, HR-eszközök) újragondolják.

Másodrendủ közpolitikai változás, amikor a kitűzött közpolitikai célok és azok sorrendje változatlan marad, de az alkalmazandó közpolitikai eszközök kapcsán markáns változás történik.

Harmadrendủ közpolitikai változás, Hall értelmezése szerint, amikor nemcsak az alkalmazott eszközök, hanem maguk a kitüzött közpolitikai célok is megváltoznak. ${ }^{8}$

Továbbá a globális elméletek vizsgálatával átfogóbb képet kaphatunk arról, hogy hogyan történhet a közpolitika változása.

A „nagy ugrás” (large leaps) elmélet hívei felismerik, hogy amikor a körülmények megfelelőek, a változás hirtelen, nagyban bekövetkezhet. Frank Baumgartner és Brian Jones úgy gondolták, hogy ha a változáshoz szükséges összes feltétel együttállása egyszerre megvalósul, a változás exponenciális lesz, nem inkrementális. Ahogy a nagy ugrás kifejezés is jelzi, rövid idő alatt bekövetkező átfogó, elsöprő erejü változások kialakulásáról van szó.

A Policy Windows elmélet John Kingdon klasszikus elmélete a napirend meghatározásához kapcsolódik, amelynek központi kérdése, hogy némely kérdések, problémák miért kapnak figyelmet a politikai folyamatban, míg mások pedig nem. A Policy Windows vagy Agenda-Setting elmélet (Kingdon) szerint a változás létrejöhet, ha a résztvevők sikeresen összekapcsolják a napirend két vagy több összetevőjét (például a probléma meghatározásának módja, a probléma politikai megoldása és/vagy a közpolitikai probléma politikai légköre).

Koalícióelmélet, amelyet Paul Sabatier és Hank Jenkins-Smith fejlesztett ki. Az ezt az elméletet alkalmazó szószólók úgy vélik, hogy a közpolitikai változás összehangolt tevékenység mentén történhet a kormányon kívüli egyének és szervezetek bevonásával.

A politikai elit vagy hatalmi elit elmélet szerint a hatalom néhány ember kezében összpontosul. Ennek a szociológiai elméletnek hosszú története van, többek között C. Wright Mills The Power Elite címü 1956-ban megjelent könyvében, amely a hatalom és a társadalmi osztályok struktúráit írja le az amerikai társadalomban (például politikai, katonai és gazdasági elit) és azt, hogy miként lépnek kapcsolatba a közpoliti-

7 Paul Pierson: Politika az időben: történelem, intézmények és társadalmi elemzés. Princeton University Press, 2004.

8 Kaiser Tamás (szerk.): A modern kormányzás koncepcionális és közpolitikai keretei. Hazai és nemzetközi dimenziók. Budapest, Dialóg Campus, 2019. 
kai folyamatokban és miként befolyásolják azt. A hatalmi elitek elmélete szerint a politika megváltoztatása úgy történik, hogy közvetlenül a hatalommal rendelkezőkkel dolgozunk együtt a döntések meghozatalában vagy a döntéshozatal befolyásolásában.

A rendszerelmélet, amelyet nagyrészt Clarence Stone-nak tulajdonítanak, azt állítja, hogy a kormánynak együtt kell mủködnie a célok és eredmények elérése érdekében. Ezeket a kollektív csoportokat „rezsimeknek” nevezi. Fontos, hogy a rezsim tagjai erőforrásokkal rendelkeznek, ideértve a stratégiai tudást és a kapacitást, vagy kapcsolati, pénzügyi és egyéb erőforrásokat. A rendszerelmélet szerint a politikai változás a befolyásos személyek támogatásával és a politikai döntéshozók felhatalmazásával történik.

\subsection{Közpolitikai siker és kudarc (policy success and failure) és a kettö közötti szürke zóna}

A közpolitika főszereplői, a döntéshozók előszeretettel állítják, hogy egy-egy közpolitikai folyamat, döntés sikeres, míg az e döntések hatásait és eredményeit érzékelők sok esetben inkább kudarcként foglalják keretbe ezen irányelveket. A valóság az, hogy a közpolitika eredményei gyakran valahol e két szélsőség között helyezkednek el. Kiegészítve azzal, hogy a közpolitikának természetesen több dimenziója van, a tények és azok értelmezése szerint bizonyos szempontból gyakran sikeresnek mondhatók, másokban azonban nem. A közpolitika elemzése számos szereplő bevonásával és számos fórumon zajlik, amelynek eredményei a nyilvánosság elé kerülnek, például kormányzati nyilatkozatok, újságcikkek, nem kormányzati hírek és tudományos cikkek révén. Annak ellenére, hogy a látszólag soha véget nem érő vizsgálat és állítások szerint „a politika sikeres volt”, a hiteles lezárás a politikai döntések sikerének kérdésében sokszor vitatható. Természetesen a politikai döntések gyakran esnek szubjektív megítélés alá, és egyes politikai szereplők által sikeresen megfogalmazott politikákat mások sikertelenként értékelhetnek..$^{9}$ Intuitív módon tudjuk, hogy a teljes siker ideálja ritkán teljesül. Néhány hiányosság vagy eredménydeficit gyakorlatilag minden politikai döntési eredményt átjár. A politikatudományokból hiányzik egy átfogó heurisztikus keretrendszer, amely lehetővé tenné az elemzők számára, hogy a politikák többféle kimenetelét megközelítsék a sikerek és kudarcok sokszoros, bináris retorikáján túlmutató módon. Bovens ${ }^{10}$ igyekezett egyértelmủen meghatározni a politikai sikert, amellyel párhuzamosan kidolgozta azt az analízist, amely e meghatározás poláris ellentéte, a közpolitikai kudarc és a különböző árnyalatok között bontakozik ki. A szakirodalom széles skálájára támaszkodva szemlélteti, hogy a siker és a kudarc miért kapcsolódik össze menthetetlenül egymással. Miért van szükségünk új

9 Frank Fischer: Reframing Public Policy: Discursive Politics and Deliberative Practices. Oxford, Oxford University Press, 2003; Deborah Stone: Policy Paradox: The Art of Political Decision Making. New York, W. W. Norton, 2002.

10 Mark Bovens - Paul 't Hart - B. Guy Peters (szerk.): Success and Failure in Public Governance: A Comparative Analysis. Cheltenham, Edward Elgar, 2001a. 
megközelítésre? Először is, a szakpolitikák értékeléséről és a fejlesztésről szóló szakirodalom közel áll Lasswell elképzeléséhez. A lasswelli kritériumok a megbízható információk nyújtásától a döntéshozatali folyamat minden tagját érintik, a belső és külső értékelés szükségességét is hangsúlyozva. A kudarc meghaladja alkalmazási körét, kivéve azt az általános felismerést, hogy a célok esetleg nem teljesülnek. A korabeli írásokban rendkívül hangsúlyosan jelenik meg az értékelés szerepe a politika megerösítésében és a tanulásban. ${ }^{11} \mathrm{~A}$ szakpolitikai elemzés fejlődésével a viták és a módszerek is változnak. A logika az, hogy a szakpolitikai siker elérése a jó politika kialakításában rejlik, a javasolt politikák várható előzetes hatásainak értékelésében, ahelyett, hogy egyszerüen az utólagos értékelésre támaszkodnának. Általánosságban elmondható, hogy a szakpolitikák értékeléséről és fejlesztéséről szóló szakirodalom különféle nézeteket tartalmaz a sikerről (általában implicit), a politikai célokat adottnak tekintve, ezzel a siker a célok és az eredmények elérésében rejlik. ${ }^{12}$ Mások szkeptikusabbak abban, hogy érdemes a politikai döntések értékelését elbagatellizálni, mert ezzel elkerülhető azok társadalmi megkérdőjelezése. Hajlamosak azt feltételezni, hogy a sikeres politika visszaszorítja a hatalmi egyensúlyhiányt, csökkenti az egyenlőtlenségeket és bevonja az érdekelteket a politikai célok megfogalmazásába és az eredmények értékelésébe.

\subsection{A siker és a kudarc alapjai}

Meg kell értenünk a politika különböző dimenzióit, hogy felismerjük a sikerek és kudarcok megnyilvánulási módjait. A köztük lévő feszültségek segítenek megmagyarázni a politika legérdekesebb jellemzőit és dinamikáját. Ezek a különbségek bekövetkezhetnek a folyamatban, a programokban és az eredményekben. Lasswell, Lindblom és Easton hagyományosan fó problémának magát a folyamatot tekinti. A kormányok lényegében azonosítják a problémákat, megvizsgálják a lehetséges politikai alternatívákat, konzultálnak vagy sem, és a döntéseket meghozzák. Minden ilyen tevékenység magában foglalja a különféle választások előnyeinek és hátrányainak mérlegelését, például ki, mikor és hogyan konzultál, valamint mérlegeli a különböző politikai megoldások lehetőségeit és kockázatait a döntés meghozatala előtt. A kormányok dolgoznak és sikerrel járnak és/vagy kudarcot vallanak. A programokat a kormányok alkotják. Ezek azok, amelyek konkrét formát képesek adni a politikai nyilatkozatok általános szándékainak. Ha teljes mértékben megértjük a politika és a kormányok többdimenziós jellegét, el kell ismernünk, hogy a programoknak politikai következményei vannak. A kormányzati döntések (ideértve a döntések időzítését, valamint az egyes cselekvési vagy tétlenségi formák szimbolikáját) kihatással vannak a politikusok hír-

11 Dipak K. Gupta: Analyzing Public Policy: Concepts, Tools, \& Techniques. Washington, DC, CQ Press, 2011.

12 George A. Boyne: What is Public Sector Improvement? Public Administration, 81. (2003), 2. 211-227; George A. Boyne: Explaining Public Service Performance: Does Management Matter? Public Policy and Administration, 19. (2004), 4. 100-117. 
nevére és választási kilátásaira, valamint a politikai menetrend kezelésének képességére. Számos politikai elemző megvizsgálta a politikai fellépés politikai következményeit, és a politikaimagatartás-tanulmányok általában a szavazatok megnyerésének szempontjából értékelik a politikákat. A kormányok politikát folytatnak és sikeresnek és/vagy sikertelennek bizonyulhatnak ebből a szempontból.

\subsection{A közpolitikai krízis, válság}

A politikatudományi szakirodalom gyakran foglalkozik az exogén sokk fogalmával. Legtöbbször a politika destabilizálását okozó válságok kerülnek a hibáztatási mechanizmusok középpontjába. Például Greener azt állítja, hogy exogén sokk új politikai paradigmákat eredményezhet. Ennek eredményeként a tudósok igyekeztek tökéletesíteni a válságok azonosíthatóságát és a kritikus csomópontok megállapítását elősegítő mechanizmusokat. Egyfelől, a válság tekinthető a vezető szempontjából exogén jellegűnek, amelyre reagálnia kell; másfelől, a vezetői cselekvés által befolyásoltnak, azaz endogén jellegűnek. A javarészt az első válságfelfogással dolgozó irodalmak - nevezhetjük őket strukturalistáknak - szerint a vezetőknek magyarázatot kell adniuk a válságra, esetleg válaszaik révén némiképp formálva azt, végül pedig tanulniuk kell az eseményekből. ${ }^{13}$

Érdemes megvizsgálni, hogy miként definiálható a politika normál állapota és ehhez képest az exgén sokk fogalma. A politika normál állapotát jelöli, amikor nincs rendkívüli helyzet vagy válság, nem veszélyezteti semmi az intézményeket vagy a kialakult konvenciókat, az átlagosnál nem nagyobb a politikai döntésekre nehezedő időbeli nyomás. A kormányzat politikája alapvetően lassan, fokozatosan változik. Az ilyen szituációkban a szabályok és kötelességek, normák és konvenciók nincsenek nyomás alatt, hisz a bizonytalanság e szintje bele van kalkulálva a politikai folyamat „forgatókönyvébe”. Az exogén sokkok (strukturalista forgatókönyv) megkérdőjelezik a normális ügymenetet és a bevett gyakorlatot, a válságkezelés mégis konvencionális eszközökkel történik, célja pedig a kontingencia ${ }^{14}$ azonnali csökkentése. Az exogén sokkok mindig kétségbe vonják a konvencionális autoritásokat és a normál politika irányát, de a válság természete és súlyossága sohasem magától értetődő, mindig vita tárgyát képezi. A külső sokkok, mint például a természeti katasztrófák, világgazdasági válság és terrorcselekmények, globális pandémia gyors reagálást követelnek a politikai vezetőktől. Az újradefiniált válságok esetében a háttér- és az operatív kontingencia egyformán magas. Mindez annyit jelent, hogy a politikai cselekvő egy őt ért külső sokkra nem konvencionális választ ad, hanem - a tétet megemelve - a körülményeket nem anomáliaként, hanem rendszerszintű hibaként interpretálja. Azonban fontos

13 Körösényi András - Illés Gábor - Metz Rudolf: A politikai vezetők szerepe válsághelyzetekben. In Körösényi András (szerk.): Viharban kormányozni: Politikai vezető́k válsághelyzetekben. Budapest, MTA TK PTI, 2017. 9-48.

14 Kontingencia: szituációelmélet; az esetlegesség elve, előre nem látott esemény, veszélyforrás. 
megjegyezni, hogy mindez nem pusztán a válság súlyosságának, mélységének és természetének retorikai eszközökkel való eltúlzása. ${ }^{15}$

Az általunk vizsgált két globális kiterjedésű krízis, amelyet a magyarországi helyi önkormányzatok átéltek és jelenleg is benne élnek, jellegüknél fogva különbözők. Több mint egy évtizede a 2008-2009-es gazdasági és pénzügyi világválság és vele a globális világgazdaság káros turbulenciáinak való kitettség (például önkormányzati devizaadósság, beszúkülő fiskális mozgástér és romló állami finanszírozás), a 2020-as Covid-19-járvány okozta pandémia időszakában közvetlenül az egészségügyi veszélyhelyzet, közvetett módon pedig a gazdasági visszaesés okozta krízisek jelentettek rendszerszintü, paradigmatikus hatású kihívást a helyhatóságok számára. Az állam és önkormányzatok szerepével, szerepvállalásának mértékével és eszközeivel kapcsolatos elvárások terén igen jelentős különbségek mutatkoznak az egyes európai országok között az egyenlőtlenségekről és a kormányzati, illetve az egyéni felelősségről alkotott vélemények figyelembevétele mellett. ${ }^{16}$ Fontos tehát látni, hogy milyen kihívásokkal szembesült a magyar rendszer, és ezekre milyen módon, milyen eszközökkel igyekezett, igyekszik válaszokat adni.

\section{Az ezredforduló utáni globális krízisek makrogazdasági hatása Magyarországon}

Az ezredforduló óta két globális kiterjedésű válság hatásaival szembesült a világ. A 2008-2009-es pénzügyi és gazdasági világválság az amerikai ingatlanpiac összeomlásából alakult ki, majd villámgyorsan terjedt szét a többi kontinensen. A magyar gazdaság 2000-2006 között éves szinten még 3,5-5\%-kal bővült, azonban ez a robosztus növekedés már 2007-ben 1\%-ra mérséklődött. A második Gyurcsány-kormány megalakulását követően erőteljes kormányzati fiskális kiigazításba kezdett a közel 10\%-osra duzzadt államháztartási hiány miatt. A miniszterelnök MSZP-frakció előtt Balatonöszödön elmondott beszédének 2006. szeptember 17-i nyilvánosságra kerülése egy hosszan tartó, a teljes ciklust lefedő belpolitikai válságot eredményezett. Közvetlenül az öszödi beszéd „kiszivárgását” követően került sor a 2006-os önkormányzati választásokra, ami a jobboldali ellenzék, a Fidesz-KDNP pártszövetség látványos elöretörését hozta. ${ }^{17}$ Ebben a kiélezett politikai szituációban érte a 2008 őszén kirobbant pénzügyi és gazdasági világválság Magyarországot, amely a különböző makrogazdasági dimenziók (államadósság, lakossági és önkormányzati devizaeladósodás stb.) tekintetében már így is az egyik legsebezhetőbb EU-s tagországnak számí-

15 Körösényi-Illés-Metz (2017): i. m.

16 Kaiser Tamás - Horváth Anett: Az állami szerepvállalás területei és tendenciái: a társadalomközpontú és az államközpontú kormányzás. In Kaiser Tamás (szerk.) (2019): i. m. 33-48.

17 A 19 megyei közgyủlésből 18-ban szereztek többséget; a 24 megyei jogú városból 17-ben adják a polgármestert. Az MSZP és SZDSZ által közösen támogatott, hivatalában 1990 óta működő Demszky Gábor csak minimális előnnyel győzött Tarlós Istvánnal szemben a főpolgármesterválasztáson; a Fővárosi Közgyűlésben 1 fős többségre fogyatkozott az MSZP-SZDSZ koalíciós többség. A fővárosi kerületekben is előretört a Fidesz - 8 kerületi polgármesteri pozíciót szereztek. 
tott. A 2009-es év brutális méretủ csökkenést eredményezett az előző évhez képest: a bruttó hazai termék 6,3\%-os, a külső kereslet 4,5\%-os, a háztartások fogyasztása 6,7\%-os csökkenést mutatott. Az államadósság alig egy év alatt közel 6\%-kal növekedve elérte a GDP 78,3\%-át 2009 végére. Az egyetlen makromutató, amely a válság ellenére javuló képet mutatott, az államháztartási hiány volt, amely 2009-ben 4\%-ra csökkent (KSH, 2010). ${ }^{18}$ A csökkenő államháztartási hiány nagyban volt köszönhető az akkor már két éve töretlenül tartó kormányzati költségvetési kiigazításnak. A válság negatívan hatott a foglalkoztatásra, a munkanélküliség mértéke 2008 harmadik negyedévében 7,7\%-os volt, ami 2009 negyedik negyedévére 10,5\%-ra növekedett, ez 115 ezer fő munkahelyének elvesztését jelentette, és szektoriális összevetésben elsősorban a versenyszférát sújtotta. ${ }^{19}$

A több mint egy évtizeddel korábbi válságidőszakhoz képest Magyarország 2020 tavaszán jóval kiegyensúlyozottabb makrogazdasági kondíciókkal rendelkezett. 2019 utolsó negyedévében a GDP még 4,9\%-kal haladta meg az előző év hasonló adatát. 2020 márciusában ért el a járvány Magyarországra, és már a hónap közepén „bezárt” az ország, hasonlóan Európa más államaihoz. A járvány és szinte az összes ágazatot érintő „bezárkózás” (lockdown policies) jelentős visszaesést eredményezett néhány hónap leforgása alatt. 2020 harmadik negyedévében a GDP már 4,6\%-kal volt alacsonyabb, mint egy évvel korábban..$^{20}$ Romlottak a külkereskedelmi adatok, növekedtek a fogyasztói árak, a költségvetési hiány a második negyedévben a GDP 9,1\%-a volt, ami az előző év azonos időszakához képest nagyon jelentős romlást mutat. ${ }^{21}$ Amíg 2020. január-március hónapokban a munkanélküliek átlagos létszáma 173 ezer fő volt (3,7\%-os munkanélküliségi ráta), csak március hónapban mintegy 56 ezren veszítették el állásukat. A 2020. augusztus-október időszakban a munkanélküliek átlagos létszáma már 202 ezer fö (4,3\%-os munkanélküliségi ráta). ${ }^{22}$ Hasonlóan a 2008-2009-es gazdasági krízishez a koronavírus-járvány eltérő mértékben sújtotta a különböző ágazatokat, a korlátozások különösen hátrányosan érintették a vendéglátás vagy a turizmus világát. Jól látható, hogy a koronavírus-járvány előtt az ország kedvezőbb makromutatókkal rendelkezett, mint 2008 őszén a pénzügyi és gazdasági világválság előestéjén. Amíg a költségvetési szektorban 2006 óta tapasztalható volt egy folyamatos fiskális megszorítás, addig 2020 elején már közel félévtizedes gazdasági fellendülésen volt túl Magyarország.

18 Központi Statisztikai Hivatal: A válság hatása a munkaerőpiacra. Budapest, (2010b. április).

19 Központi Statisztikai Hivatal (2010b. április): i. m.

20 Lásd: www.ksh.hu/gyorstajekoztatok\#hu/document/gdp2009

21 Lásd: www.ksh.hu/gyorstajekoztatok\#hu/document/krm2006

22 Lásd: www.ksh.hu/docs/hun/xftp/gyor/mun/mun2003.html; www.ksh.hu/docs/hun/xftp/gyor/ mun/mun2010.html 


\section{A kormányzás alkotmányos környezete és közjogi mozgástere}

2008-2009-ben, illetve 2020-ban részleteiben eltérő közjogi szabályozás volt érvényben, ez érintette az alkotmányos, alaptörvényi szabályozást, a „sarkalatos” helyi önkormányzati törvényi hátteret, valamint a szakágazati jogi kereteket. 2008-2009-ben a rendszerváltás időszakában átfogó revízión átesett 1949. évi XX. törvény az Alkotmány volt érvényben, amelynek a IX. fejezete szólt a helyi önkormányzatokról. Az önkormányzatok életét átfogóan a helyi önkormányzatokról szóló 1990. évi LXV. törvény (Ötv.) szabályozta. A különleges jogrend úgynevezett veszélyhelyzeti esetéről a 2012 előtt hatályos Alkotmány így fogalmazott: „Veszélyhelyzetben és megelőző védelmi helyzetben a Kormány az Országgyülés felhatalmazása alapján egyes törvények rendelkezéseitől eltérő rendeleteket és intézkedéseket hozhat. A veszélyhelyzetben és a megelőző védelmi helyzetben alkalmazható szabályokról szóló törvény elfogadásához a jelenlévő országgyủlési képviselők kétharmadának szavazata szükséges."23

A 2006 tavaszán ismét választást nyert MSZP-SZDSZ kormánykoalíció a parlamenti helyek egyszerü 50\% feletti többségével rendelkezett. A 2006-os történések miatt állandósult belpolitikai eszkalációt kormányzati szemszögből tovább rontotta a 2008-as tavaszi koalíciós szakadás, amelynek a következménye egy kisebbségi szocialista kabinet lett. Az ősszel kirobbanó gazdasági válság kormányzati menedzselésének parlamenti biztosítása rendkívül ingataggá vált - a többséget csak valamely ellenzéki párt (általában a szabaddemokraták) külső támogatásával lehetett biztosítani, ahogy az történt a 2009. és 2010. évi költségvetési törvények elfogadásánál is.

2020-ban a koronavírus magyarországi megjelenésekor a 2012-ben életbe lépett Alaptörvény volt az irányadó közjogi keret, amelyet a 2010 tavaszán megalakult Országgyülés 2/3-os kormánypárti (Fidesz-KDNP) többsége fogadott el. Ez a parlament szavazta meg a Magyarország helyi önkormányzatairól szóló 2011. évi CLXXXIX. törvényt (Mötv.) is. 2010 után paradigmatikus változások érték a helyi közfeladat-ellátás rendszerét: szűkült az önkormányzatok fenntartói, hatósági és közszolgáltatási feladatköre, ${ }^{24}$ szigorodott a gazdálkodási mozgástér (kormányzati hitelfelvételi engedély, a feladatfinanszírozás megjelenése stb.), a helyi hatósági igazgatásban a megújított területi államigazgatás ${ }^{25}$ vált dominánssá. Az állam szerepének

23 1949. évi XX. törvény 35. $\mathbb{S}(3)$ bek.

24 Az önkormányzatok korábbi kórház- és közoktatásiintézmény-fenntartó feladatai teljesen eltủntek. Szociális és gyermekvédelmi területen szintén jelentős intézményi csökkenés volt tapasztalható. Erős átalakulások történtek a közüzemi szolgáltatásoknál (hulladékgazdálkodás; szennyvíz- és ivóvíz-gazdálkodás stb.) szintén az állam szerepének a felértékelődésével. A helyi hatósági igazgatásban az általános hatáskörủ új területi államigazgatási szervek számos kompetenciát vettek át az önkormányzatoktól - szociális segélyezés; gyám- és gyermekvédelem; foglalkoztatáspolitika. Az önkormányzatok és állam közötti roppant hatáskörtranszfer bemutatásával és értékelésével kiterjedt szakirodalom foglalkozik, és mivel jelen tanulmány témája alapvetően nem erre irányul, így eltekintünk e folyamat bővebb bemutatásától.

Megyei és fővárosi kormányhivatalok; járási és fővárosi kerületi hivatalok. 
jelentős megerősítését eredményezték az újonnan megalkotott vagy jelentősen módosított szakágazati törvények. ${ }^{26}$

A kormányzati válságkezelés vonatkozásában meghatározó a korábbi Alkotmányhoz képest az Alaptörvényben jóval részletesebben szabályozott úgynevezett különleges jogrend, ${ }^{27}$ ennek esetei: a rendkívüli állapot, a szükségállapot, a megelőző védelmi helyzet, az Alaptörvénybe 2016-ban bekerült terrorveszélyhelyzet, ${ }^{28}$ a váratlan támadás, valamint az alkotmányos veszélyhelyzet. Ez utóbbi biztosította a koronavírus-járvány okozta krízisszituációban alkalmazott különleges jogrend alapját - az Alaptörvény 53. cikk (2) pontja kimondja, hogy: „A Kormány a veszélyhelyzetben rendeletet alkothat, amellyel - a sarkaltos törvényben meghatározottak szerint - egyes törvények alkalmazását felfüggesztheti, törvényi rendelkezésektől eltérhet, valamint egyéb rendkívüli intézkedéseket hozhat."

A Kormány élve az Alaptörvényben biztosított jogával 2020. március 11-én az egész ország területére alkotmányos veszélyhelyzetet hirdetett ki a 40/2020. (III. 11.) Korm. rendelettel. ${ }^{29} \mathrm{Az}$ Alaptörvény veszélyhelyzetről szóló rendelkezéseit részletezi a katasztrófavédelemről szóló 2011. évi CXXVIII. törvény (Kat.) V. fejezete. A Kat. 44. \$ bontja ki elemeiben, hogy mi is számít veszélyhelyzetnek - benne az elemi csapások, természeti eredetü veszélyek; az ipari szerencsétlenség, civilizációs eredetủ veszélyek; egyéb eredetű veszélyek. A Kat. a harmadik egyéb eredetű veszélyforrások között nevesíti a „tömeges megbetegedést okozó humánjárványt vagy járványveszélyt, valamint állatjárványt", ami a koronavírus-járványból fakadó veszélyhelyzet alapjául szolgált. A Kat. veszélyhelyzetre vonatkozó paragrafusai szerint: „Veszélyhelyzetben a települési önkormányzat képviselö-testületének, a fővárosi, megyei közgyülésnek feladat- és hatáskörét a polgármester, illetve a föpolgármester, a megyei közgyűlés elnöke gyakorolja. Ennek keretében nem foglalhat állást önkormányzati intézmény átszervezéséről, megszüntetéséről, ellátási, szolgáltatási körzeteiről, ha a szolgáltatás a települést is érinti." - ez rendkívül erős felhatalmazást biztosít veszélyhelyzetben a felsorolt önkormányzati döntéshozók számára. Szükséges szólnunk a koronavírus elleni védekezésről szóló 2020. évi XII. törvényről, amelyet a közvélemény mint „felhatalmazási törvényt” ismert meg. Ennek jogi szükségességét a kormányzati

26 2011. évi CXC. törvény a nemzeti köznevelésről; 2011. évi CLIV. törvény a megyei önkormányzatok konszolidációjáról, a megyei önkormányzati intézmények és a Fővárosi Önkormányzat egyes egészségügyi intézményeinek átvételéről; 2012. évi XXXVIII. törvény a települési önkormányzatok fekvőbeteg-szakellátó intézményeinek átvételéről és az átvételhez kapcsolódó egyes törvények módosításáról; 2012. évi XCIII. törvény a járások kialakításáról, valamint egyes ezzel összefüggö törvények módosításáról; 1993. évi III. törvény a szociális igazgatásról és szociális ellátásokról; 1997. évi XXXI. törvény a gyermekek védelméről és a gyámügyi igazgatásról.

27 Alaptörvény 48-54. cikk.

28 Ez volt az Alaptörvény hatodik módosítása 2016-ban.

29 Érdemes megjegyezni, hogy veszélyhelyzetet az Alaptörvény hatálybalépését követően nem az első esetben alkalmazta a Kormány 2020. márciusban, elötte 2013-ban már volt rá precedens, igaz nem az ország egész területére nézve, a Duna áradása és jelentős vízszintemelkedése miatt Győr-MosonSopron és Komárom-Esztergom megyék egészére, valamint Pest megye és Budapest egyes részeire vonatkozva. 
álláspont szerint az Alaptörvény veszélyhelyzetről szóló 53. cikk (3) pont kényszerítette ki, miszerint a Kormány veszélyhelyzetben alkotott rendelete „tizenöt napig marad hatályban, kivéve, ha a Kormány - az Országgyủlés felhatalmazása alapján - a rendelet hatályát meghosszabbítja”. Éppen a 15 napos folyamatos parlamenti megerősítési kötelezettség oldása érdekében a „felhatalmazási törvény” 3 . $\mathbb{\$}$ lehetőséget biztosít, hogy:

„Az Országgyülés az Alaptörvény 53. cikk (3) bekezdése alapján felhatalmazza a Kormányt, hogy a veszélyhelyzetben az Alaptörvény 53. cikk (1) és (2) bekezdése szerinti kormányrendeletek hatályát a veszélyhelyzet megszünéséig meghosszabbítsa”, ugyanakkor azt is tartalmazza, hogy „[a]z Országgyülés a veszélyhelyzet megszűnését megelőzően az (1) bekezdés szerinti felhatalmazását visszavonhatja".

A „felhatalmazási törvény” biztosította, hogy a Kormány veszélyhelyzetben alkotott rendeletei egészen a veszélyhelyzet visszavonásáig automatikusan érvényben maradjanak, így ne legyenek se közjogi, se politikai értelemben az országgyủlési megerősítésnek kiszolgáltatva. Amíg a veszélyhelyzet március 11-i kormányzati kihirdetését a parlamenti ellenzéki pártok (MSZP, Párbeszéd, Jobbik, LMP, Demokratikus Koalíció) egységesen elfogadták, nem vitatva a veszélyhelyzet elrendelésének jogosságát, addig a „felhatalmazási törvényt” már feleslegesnek, egyes megszólalások a „demokrácia csorbításaként" aposztrofálták. ${ }^{30} \mathrm{~A}$ különleges jogrend keretében minősített alkotmányos jogok megtalálhatók az európai alkotmányokban. Hol részletesebb, hol kevésbé kifejtős formában - általában a hadi- és szükségállapot jelenik meg, de vannak országok, ahol a magyar Alaptörvényhez hasonlóan a minősített helyzetek kiegészülnek. Így például az osztrák alkotmány beszél a nyilvánosság számára jóvátehetetlen kár, valamint rendkívüli méretü elemi csapásokról. Az alkotmányos elöírások tartalmazzák az ilyenkor követendő eljárásrendet, a legfontosabb közhatalmi szervek - törvényhozás, államfo, kormányzat - hatásköreit. A pandémia „kikényszerítette", hogy a különböző országokban alkalmazzák a különleges jogrendet, ennek tapasztalatairól már készülnek a különböző tanulmányok és tudományos leírások.

A kora nyári csökkenő esetszámok hatására a Kormány 2020. június 18-án hatályon kívül helyezte a veszélyhelyzetet. ${ }^{31} \mathrm{~A}$ "felhatalmazási törvényt” az Országgyülés helyezte hatályon kívül a 2020. évi LVII. törvénnyel. A veszélyhelyzet megszüntetésével egyidejüleg a parlament kormánypárti többsége elfogadta a veszélyhelyzet megszűnésével összefüggő átmeneti szabályokról és a járványügyi készültségről szóló 2020. évi LVIII. törvényt, amely számos egyéb ügy (például fizetési moratórium) mellett az egészségügyi törvény keretében korábban már létező úgynevezett egészségügyi válsághelyzetre vonatkozóan megerősítette a Kormány különleges ágazati

30 Különösen éles bírálatok érték a „felhatalmazási” törvény mellett a rémhírterjesztőkre vonatkozó Btk, szigorítást - 2012. évi C. törvény a Büntető törvénykönyvről.

31 282/2020. (VI. 17.) Korm. rendelet a 2020. március 11-én kihirdetett veszélyhelyzet megszüntetésérỏl. 
jogköreit, feladatait. ${ }^{32} \mathrm{~A}$ különböző jogi kommentárok szerint az egészségügyi válsághelyzet nem tartozik az Alaptörvényben meghatározott különleges jogrendek körébe, ám az általános jogrendtől eltérően mégis egyfajta köztes, speciális jogrend keretében többletjogosítványokat biztosít a kabinet számára, ami felett az Országgyűlés kontrollja csak korlátozottan érvényesül. ${ }^{33} \mathrm{Az}$ őszi hónapokra radikálisan felívelő Covid19-esetszámok okán a Kormány élve az Alaptörvényben biztosított alkotmányos jogával, 2020. november 4-ével ismét életbe léptette a veszélyhelyzetet. ${ }^{34}$

Alig nyolc nappal a második veszélyhelyzet kihirdetését követően a Magyar Országgyủlés megszavazta a koronavírus-világjárvány második hulláma elleni védekezésről szóló 2020. évi CIX. törvényt, amelyben a Tisztelt Ház felhatalmazta a Kormányt, hogy a november 4-én kihirdetett veszélyhelyzetben meghozott kormányrendeletek hatályát 2021. február 7-ig meghosszabbítsa. Mivel a Covid-19 második hullámát szinte azonnal követte az angol mutáció miatt elszabadult harmadik járványhullám, így megtörtént a harmadik alkotmányos veszélyhelyzet kihirdetése is a 27/2021. (I. 29.) Korm. rendelettel, amely a 2021. február 8. - május 22 . időszakra nézve állapította meg a veszélyhelyzet időbeli hatályát. A harmadik hullám aggasztó halálozási és fertőzési adatai miatt március elején jelentős további szigorítások történtek - teljes körủ digitális közoktatás; szigorított üzleti nyitvatartás; szolgáltatói szektor korlátozása - a 104/2021. (III. 5.) Korm. rendelet a védelmi intézkedések ideiglenes szigorításáról.

2021 tavaszára a védekezés meghatározó dimenziójává a különböző vakcinákkal folytatott országos oltási folyamat vált..$^{35}$ Hasonlóan a 2020-as jogalkotási „forgatókönyvhöz” 2021. évben is az Országgyülés „felhatalmazási törvény” keretében biztosítja a Kormányt, hogy a veszélyhelyzetben meghozott kormányrendeletek hatályát a törvényben meghatározott hatályvesztésig (2021. május 22.) meghosszabbíthassa. ${ }^{36}$ Az Országgyülés 2021. május 18-i ülésén ismételten meghosszabbította a veszélyhelyzetet az őszi parlamenti ülésszakig (szeptember közepéig) - így továbbra is adott a jogi lehetőség a végrehajtó hatalom számára, hogy a veszélyhelyzetben meghozott kormányrendeletek hatályát a veszélyhelyzet végéig meghosszabbítsa.

32 Az egészségügyi válsághelyzeti és egészségügyi veszélyhelyzeti ellátásról szóló rendelkezéseket az egészségügyről szóló 1997. évi CLIV. törvény XIV. fejezete tartalmazza.

33 Ezt a speciális köztes jogrendi pozíciót jelzi, hogy a veszélyhelyzettől eltérően az egészségügyi válsághelyzet keretében alkotott rendelet nem 15 napig, hanem 6 hónapi hatályban maradhat országgyủlési megerősítés nélkül, másrészt a 6 hónap lejártát követően elég a kormányzati meghoszszabbítás: https://jogkoveto.hu/tudastar/mi-az-egeszsegugyi-valsaghelyzet

34 478/2020. (XI. 3.) Korm.rendelet a veszélyhelyzet kihirdetéséről. A kézirat 2020. decemberi lezárása időpontjában még mindig érvényben van a november 4-én életbe lépett veszélyhelyzet. A védekezés aktuális pozícióit nagymértékben meghatározza a veszélyhelyzet és egészségügyi válsághelyzet keretében meghozott kormányzati intézkedések (például esti kijárási tilalom) hatásai az esetszámokra, valamint a vakcinakísérletek és a hatósági gyógyszer-engedélyezések után 2021 elején várhatóan elinduló tömeges oltások eredményei.

35 A Kormány hivatalos tájékoztatási oldala, a koronavirus.gov.hu szerint 2021. június 11-én 5 millió 324 ezer 996 fö volt beoltva.

36 2021. évi I. törvény a koronavírus-világjárvány elleni védekezésről. 
A helyi önkormányzatok működését átfogóan szabályozó Mötv. semmilyen módon nem rendelkezik a különleges jogrend és a veszélyhelyzet kapcsán. A katasztrófavédelmi törvény teremt lehetőséget, hogy veszélyhelyzetben a polgármester, föpolgármester, valamint a megyei közgyülés elnöke személyében gyakorolhatja a települési képviselőtestületek, fővárosi és megyei közgyủlések feladat- és hatáskörét [Kat. 46. $\mathbb{S}(4)]$. Ehhez kapcsolódóan volt kormányzati felvetés még 2020 tavaszán, hogy a polgármesterek Kat.-ban meghatározott rendkívüli hatáskörét csak a megyei védelmi bizottságok jóváhagyásával gyakorolhassák, ezt viszont hamar levették a napirendről az önkormányzati szektor (s vele kormánypárti polgármesterek) erőteljes tiltakozásának hatására.

\section{Kormányzati és önkormányzati lépések, reakciók a két krízis időszakában}

A két vizsgált krízis során eltérő mozgásterek adódtak a központi végrehajtó hatalom számára. A koronavírus hatására elrendelt alkotmányos veszélyhelyzet, valamint a 2/3-os kormánypárti többség által megszavazott úgynevezett „felhatalmazási törvény" európai összehasonlításban is kiemelkedő cselekvési lehetőségeket teremtett 2020-ban a kormányzat számára. Ilyen széles mozgástér 2008-2009-ben természetesen nem volt adott. A 2006-2010-es időszak kiélezett és illékony politikai viszonyaihoz képest 2010 után kormányzati nézőpontból egy sokkal (maga)biztosabb választói és pártpolitikai bázison nyugvó évtized következett. Az országgyủlési választásokon három alkalommal $(2010,2014,2018)$ alkotmányozó kétharmados többséget szerző Fidesz-KDNP pártszövetség megrendítő vereséget mért az ellenzékre az önkormányzati választásokon 2010-ben és 2014-ben. Jelentősebb változások csak a 2019. októberi önkormányzati választásokon történtek, amikor a Fővárosi Önkormányzatot, valamint a fóvárosi kerületek túlnyomó többségét 9 év után visszavette a FideszKDNP-től az időközben jelentősen újrastrukturálódott politikai baloldal. ${ }^{37}$ Ezzel ismét kialakult egy pregnáns kormányzat - Budapest politikai törésvonal, ami ilyen direkt formában utoljára 1998-2002 között volt érzékelhető. A főváros mellett kilenc megyei jogú város, valamint jónéhány közép- és kisváros veszett el a kormánypártok számára. Ebben a politikai klímában érte az országot 2020. márciusban a koronavírus-járvány.

A következőkben komparatív alapon vázoljuk fel, hogy a két vizsgált krízis időszakában az alapvetően eltérő parlamenti pártpolitikai támogatással, hátországgal rendelkező kormányzatok milyen irányú döntés- és intézkedéssorozatot valósítottak meg a válságkezelés jegyében az önkormányzatokkal kapcsolatban. Ezeket mennyire determinálták a krízisek által keletkezett objektív körülmények (gazdasági visszaesés, a fiskális mozgástér beszűkülése, a közegészségügyi körülmények) és mennyire a már felvázolt politikai viszonyok és vele a domináns kormányzati-ellenzéki dimenzió.

37 Budapesten a 2019-es önkormányzati választásokon a Jobbik elhanyagolható pozíciókat szerzett. 
Vizsgáljuk az önkormányzatok válságra adott reakcióit, a központi kormányzat és helyi önkormányzatok közötti viszony alakulását.

\subsection{Gazdasági és pénzügyi krízis 2008-2009-ben}

2008-ra Magyarországon a kormányzat politikai tekintetben már megroggyant állapotban volt: a 2006 óta elhúzódó politikai krízis, jelentős önkormányzati pozícióvesztés és a folyamatos kormányzati fiskális megszorításokból fakadó társadalmi feszültségek miatt. Az állandósult és eszkalálódott nagypolitikai megosztottság „lecsapódott” a Kormány és a helyi önkormányzatok közötti viszonyokon, amit a kabinet a Kormány-Önkormányzatok Egyeztető Fórumának (KÖEF) felállításával igyekezett elfogadható szinten kezelni és müködtetni. ${ }^{38}$

A kiélezett helyzetben rendkívül szűk mozgástere maradt a kormányzatnak. 2006-2010. között történtek 2/3-os alkotmánymódosítások, de ezek alapvetően inkább technikai változások voltak (például az EU lisszaboni szerződés ratifikációjához szükséges alkotmánymódosítás). A valódi fontosságú parlamenti 2/3-os többséget igénylő állam- és közhatalmi kérdésekben - így az önkormányzati rendszer jövőjét illetően - már nem alakult ki politikai konszenzus. A koalíciós szakítást követően az egyszerü parlamenti többség biztosítása is csak valamely ellenzéki parlamenti párt - általában az SZDSZ - támogatásával volt biztosított a Kormány számára.

A válságkezelés során az önkormányzatokat érintő központi döntések főleg pénzügyi, fiskális jellegűek voltak. A hirtelen berobbanó gazdasági krízistől függetlenül az 1990 óta létező magyarországi helyi önkormányzati modell rendszerszintű anomáliái (alulfinanszírozottság, forrás nélküli állami feladattelepítés a településekre, a 2006 után „meglóduló” önkormányzati eladósodás stb.) ekkor már közismertek voltak. Habár a Kormány 2006 nyarán a parlamentnek még benyújtott egy átfogó önkormányzati reformcsomagot, ez azonban a Fidesz-KDNP támogatásának hiányában lekerült a napirendről. Nemzetközi tapasztalat, hogy az átfogó krízisek nem igazán alkalmasak a rendszerszintű átalakításokra és azok konszolidációjára, helyette sokkal inkább az azonnali kármentés, valamint a helyzet rövid távú stabilizálása jelenik meg reális célkitűzésként.

Az önkormányzatokat érintő kormányzati válságkezelés 2008-2009-ben a rendszeren belüli „tűzoltó” jellegű megoldásokra korlátozódott. Ezek közül meghatározók a bérpolitikai intézkedések voltak - a közszféra következő évi béreinek 2008-as szinten történő befagyasztása, a 13. havi juttatások felfüggesztése. A megszorító intézkedések folytatódtak 2009 tavaszán az akkor hivatalba lépő Bajnai-kormány révén a 13. havi köztisztviselői, közalkalmazotti bérek végleges eltörlésével. Az önkormányzati forrásszabályozás kereteihez azonban érdemben nem nyúltak, ehhez nemcsak a jobboldali parlamenti ellenzék, de az önkormányzati szektor támogatása is hiányzott.

38 A KÖEF működéséről bővebben lásd Szabó Tamás: KÖEF a mérlegen: közpolitikai elemzés a Kormány-Önkormányzatok Egyeztető Fórum működéséről. Politikatudományi Szemle, 18. (2009), 3. 112-131. 
Így megmaradt a településeknek helyben maradó SZJA aránya, egyes költségvetési elöirányzatok minimális mértékben még növekedtek is (például az EU Önerő Alap, ÖNHIKI-alap, többcélú kistérségi társulások támogatása). Szűk, néhány milliárd Ft-os kerettel új programok is bekerültek a 2009-es költségvetésbe - önkormányzati diáksportfeladatok, iskolapszichológusi hálózat fejlesztése. A bérpolitikai intézkedések mintegy 150 milliárd Ft-tal csökkentették az önkormányzati szektor bevételi forrásait. ${ }^{39} \mathrm{~A} 2010$. évre vonatkozóan sem változott alapvetően az önkormányzati forrásszabályozás rendszere, bár számos előirányzat összege csökkent - például egyes közoktatási normatívák ${ }^{40}$ vagy kedvezményes étkezési támogatások. ${ }^{41}$

A csökkenő központi támogatásokat az önkormányzatok a saját bevételek - kiemelten a helyi adók - növelésével akár érdemben ellensúlyozhatták volna, azonban ez reális alternatívaként nem jelent meg: egyrészt gazdasági válságidőszakban az adóemelés rendkívül kockázatos, másrészt a helyi adóztatásban rejlő lehetőségeket így is kimerítette az időközben egyre inkább forráshiányossá váló és eladósodó önkormányzati szektor. 2009-re mindössze 45 olyan magyarországi település maradt, amely semmilyen jogcímen nem vetett ki helyi adót. 2001-2009 között a helyi adóbevételek mennyisége több mint a duplájára emelkedett (266 milliárd Ft-ról 566 milliárd Ft-ra). Ez a növekedés kimutatható volt még a válság évében is, 2009-ben 13 milliárd Ft-tal növekedett az előző évhez képest a települések helyi adóbevétele.

Miközben a válságkezelés jegyében csökkentették az önkormányzati normatívákat, a forrásszabályozási modell változatlan maradt. Ugyanakkor a válság alatt jelentősen felgyorsult a 2005-2006-tól egyre súlyosabb méretű önkormányzati eladósodás (különösen a devizában való kötvénykibocsátás). Érdemes hangsúlyozni, hogy a pénzügyi és gazdasági válság közepette több önkormányzat is a fejlesztésekbe való "előre menekülésről” döntött mint a kríziskezelés egy lehetséges módjáról - ezt jelzi, hogy 2010-ben az önkormányzati alrendszer kötvénykibocsátásából származó kötelezettség csak 2010. évben 564 milliárd Ft-tal növekedett. Viszont 2009. évben már viszszafogottabb volt az önkormányzatok kötvénykibocsátási gyakorlata a 2007-2008-as évekhez viszonyítva. A 2009-es önkormányzati kötvénykibocsátások döntően az EU-s fejlesztési pályázatokhoz szükséges önrész biztosítását szolgálták.

Ilyen körülmények között a szektor adósságállománya 2010-2011-re gyakorlatilag kezelhetetlenné vált, kikényszerítve az önkormányzatok adósságkonszolidációját, amit viszont már a következő kabinet (második Orbán-kormány) valósított meg. Előbb a megyei önkormányzatok mintegy 170 milliárd Ft-os, majd azt követően a települési önkormányzatok felhalmozódott tartozásainak állami átvállalása következett.

39 Állami Számvevőszék: Észrevétel a Magyar Köztársaság 2009. évi költségvetési törvényjavaslata javasolt módositásához (2008. november).

402013 előtt a közoktatás finanszírozása alapvetően az államháztartás helyi önkormányzati alrendszerén keresztül történt.

41 Állami Számvevőszék: Vélemény a Magyar Köztársaság 2009. évi költségvetési javaslatáról (2009. szeptember). 
A 2012-2014 között lezajlott önkormányzati adósságkonszolidáció során az állam mintegy 1344 milliárd Ft egykori önkormányzati adósságot konszolidált.

\subsection{A koronavírus-járvány 2020-2021-ben}

A 2020-as koronavírus-járvány mint közegészségügyi krízis tette szükségessé a különleges jogrend (veszélyhelyzet) kormányzati bevezetését. A 40/2020. (III. 11.) Korm. rendelet által elrendelt első veszélyhelyzet időszakában több olyan döntés született rendeleti formában, amelyek azonnali bevételkiesést okoztak a települések számára. A korábban az állam és önkormányzatok közötti megosztott adónak minősülő gépjármủadó településeknél maradó $40 \%$-os részét központosították. ${ }^{42} \mathrm{~A}$ helyi adónak minősülő idegenforgalmi adó megfizetését felfüggesztették 2020. december 31. határidővel, ${ }^{43}$ továbbá az önkormányzati parkolási (várakozási) ${ }^{44}$ és a vendéglátó egységek számára fizetendö közterülethasználati díjakat. ${ }^{45}$ Ezek együttesen jelentős bevételcsökkenést eredményeztek az önkormányzatok számára. ${ }^{46}$ A Covid-19esetszámok csökkenése miatt a Kormány a veszélyhelyzetet 2020. június 18-i határidővel hatályon kívül helyezte, így a fenti intézkedések is érvényüket veszítették. Azóta a koronavírus-járvány őszi második hullámának hatására ismét elrendelt veszélyhelyzet ${ }^{47} \mathrm{~s}$ vele a különleges jogrend közepette újabb, az önkormányzatok gazdasági mozgásterét korlátozó intézkedések születtek kormányrendeleti formában. Ezek radikális mértékben korlátozták a települések adóztatási, díjszabási mozgásterét: rendeletileg megtiltották, hogy 2021-ben a helyi önkormányzatok új helyi adókat vessenek ki, illetve növeljék a helyi adók 2020. évi mértékét, valamint azt, hogy a hatályos helyi adómentességeket és kedvezményeket módosítsák a 2021. adóévben ${ }^{48}$ A települések gazdálkodási mozgásterére legnagyobb hatással azonban várhatóan a helyi iparüzési adó 2021. évi mértékét befolyásoló 639/2020. (XII. 22.) Korm. rendelet lesz, amely az egyéni vállalkozók és a KKV-k esetében felére csökkenti az önkormányzatok

42 92/2020. (IV. 6.) Korm. rendelet a Magyarország 2020. évi központi költségvetésének a veszélyhelyzettel összefüggő eltérő szabályairól.

43 140/2020. (IV. 21.) Korm. rendelet a Gazdaságvédelmi Akcióterv keretében a koronavírus-járvány gazdasági hatásainak mérséklése érdekében szükséges adózási könnyítésekről.

44 87/2020. (IV. 5.) Korm. rendelet a várakozási díj megfizetésének a veszélyhelyzet során alkalmazandó eltérő szabályairól.

45 168/2020. (IV.30.) Korm. rendelet a védelmi intézkedésekről.

46 A legnagyobb hazai önkormányzati érdekszövetségnek a Települési Önkormányzatok Országos Szövetségének (TÖOSZ) 2020. tavaszi felmérése szerint a gépjárműadó 40\%-ának központosítása a kistelepüléseket érintette főleg hátrányosan; az idegenforgalmi adó, illetve a parkolási és közterülethasználati díjak felfüggesztése a városokat, megyei jogú városokat és a fővárost, fövárosi kerületeket érintette nagyobb arányban. A TÖOSZ felmérésről bővebben lásd Települési Önkormányzatok Országos Szövetsége: A TÖOSZ felmérésében résztvevő önkormányzatok több mint felének legfeljebb kéthónapnyi tartaléka van. (2020. június 9.).

47 478/2020. (XI. 3.) Korm. rendelet a veszélyhelyzet kihirdetéséről.

$48535 / 2020$. (XII. 1.) Korm. rendelet a koronavírus-világjárvány nemzetgazdaságot érintő hatásának enyhítése érdekében szükséges helyi adó intézkedésről. 
által 2020-ban kirótt helyi iparűzési adó mértékét. ${ }^{49}$ Könnyen megjósolható, hogy a 2021. év egyik meghatározó közpolitikai törésvonala lesz a helyi iparüzési adó. ${ }^{50}$

A veszélyhelyzet alatt meghozott kormányrendeletek egyfajta „közpolitikai tesztüzemként" is értelmezhetők: az ideiglenes hatályú kormányrendeletekben lefektetett szakpolitikai döntések kormányzati akarat esetén tovább transzformálhatók törvényi keretek közé. Így került be a gépjármủadó teljes elvonása ${ }^{51}$ az egyes adótörvények módosításáról szóló 2020. évi CXVIII. törvénybe. Hasonló „ügymenetben” járt el a kormányzat az úgynevezett különleges gazdasági övezet jogintézmény megte-

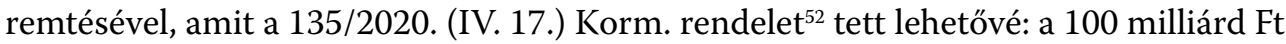
feletti költségigényủ új vagy már meglévő beruházás megvalósításául szolgáló helyszínt a Kormány rendelettel különleges gazdasági övezetté nyilváníthatja, ezzel a beruházás helyszínéhez kapcsolódó önkormányzati feladatok ellátását és az érintett terület tulajdonjogát a megyei önkormányzathoz rendelve, ez szolgáltatta a jogalapot az úgynevezett lex Göd elfogadásához. ${ }^{53} \mathrm{Az}$ ideiglenes hatályú kormányrendelet közjogi „bebetonozását” a Magyar Országgyủlés kormánypárti többsége valósította meg a különleges gazdasági övezetről és a hozzá kapcsolódó egyes törvények módosításáról szóló 2020. évi LIX. törvény elfogadásával, ami bizonyos, nem elhanyagolható módosításokat leszámítva, ${ }^{54}$ megerősítette a jogintézményt - ezt követően a 294/2020. (VI. 18.) Korm. rendelet immár végleges jelleggel kijelölte Göd közigazgatási területén a különleges gazdasági övezetet és vele a megyei önkormányzat joghatóságát. ${ }^{55} \mathrm{Az}$ is látható, hogy a valóban átmenetinek, kifejezetten a veszélyhelyzet időszakára szánt központi intézkedések esetében a törvényi szintre való emelés nem jelenik meg szándékként - így a veszélyhelyzet során felfüggesztett önkormányzati parkolási díjak törvényi szintű megszüntetése láthatóan nem opció a kormányzat számára hosszú távon. A 2020. novemberben kihirdetett második veszélyhelyzet alatt

49 639/2020. (XII. 22.) Korm. rendelet a koronavírus-világjárvány nemzetgazdaságot érintő hatásának enyhítése érdekében szükséges egyes intézkedésekről.

50 Több önkormányzati szövetség, így a Magyar Önkormányzatok Szövetsége és a Települési Önkormányzatok Országos Szövetsége jelezte tiltakozását, a Megyei Jogú Városok Szövetsége pedig rendkívül megosztott a helyi iparúzési adó kérdésében attól függően, hogy kormánypárti vagy ellenzéki vezetésű városokról van szó.

51 2021-től a gépjárműadó esetében az adóhatósági feladatokat már nem a helyi önkormányzatok, hanem az állami adó- és vámhatóság látja el.

$52135 / 2020$. (IV. 17.) Korm. rendelet a veszélyhelyzettel összefüggésben a nemzetgazdaság stabilitásának érdekében szükséges intézkedésekről.

53 136/2020. (IV. 17.) Korm. rendelet a Göd város közigazgatási területén különleges gazdasági övezet kijelöléséről - amely veszélyhelyzetben hozott rendelet által kijelölt eredetileg a város tulajdonában lévő a Samsung gyár által érintett ingatlanokra a Pest Megyei Önkormányzat tulajdon- és ezzel helyi adóztatási jogát állapította meg. Zongor Gábor: Új közigazgatási területi egység: a különleges gazdasági övezet. Új Magyar Közigazgatás, 13. (2020a), 3. 38-41.

54 A törvény levitte a beruházási értékhatárt 5 milliárd Ft-ra, másrészt a törvény hatálya alól kivette a főváros, valamint a megyei jogú városok területét. A különleges gazdasági övezetről lásd bővebben Zongor (2020a): i. m.

55 Göd az „első és jelenleg egyetlen fecske”, a jövő egyik fontos települési önkormányzatokat érintő dilemmája, hogy a kormányzat milyen mértékben kíván élni a különleges gazdasági övezetté való nyilvánítás lehetőségével. 
ismét felfüggesztették az önkormányzati parkolási díjakat. ${ }^{56} \mathrm{~A}$ közvetlen védekező intézkedéseket szintén az ideiglenes hatályú kormányrendeletek mentén szabályozta a Kormány - így a maszkviselés, az éjszakai kijárási tilalom, az idősek vásárlási szabályai, a rendezvényekre vonatkozó elöírások, a köznevelés és felsőoktatás működésére irányuló átmeneti előírások. Ugyanakkor a kormányzat törvényben igyekezett a saját politikai és intézkedési mozgásterét biztosítani a koronavírus második hullámának időszakára. ${ }^{57}$

A kormányzat számára az Alaptörvényben kodifikált veszélyhelyzet biztosít különleges közjogi és politikai mozgásteret. A veszélyhelyzet alatt meghozott kormányrendeletek azon túl, hogy alkalmasak az azonnali válságkezelésre, láthatóan az általános törvényalkotás kísérleti laboratóriumai, „politikai és közjogi előszobái” - ezt példázza a gépjármüadó teljes „államosítása”, vagy a különleges gazdasági övezet törvénybe foglalása. A felvázolt folyamat beilleszthető a koronavírus-járvány elleni védekezés mentén a központi döntési szintet felerősítő nemzetközi politikai trendbe, ezt a szakirodalom találóan csak úgynevezett koronacionalizmusnak nevezi. Annak a kérdésnek a megválaszolása összeurópai összevetésben azonban még várat magára, hogy a pandémia időszakában meghozott kormányzati döntések mennyiben tekinthetők a helyi önkormányzatokat érintő átmeneti korlátozásoknak vagy egy hosszabb távú centralizációs tendencia kezdő elemének. Ugyanakkor ez Magyarországon már kevésbé merülhet fel kérdésként, ismerve a 2010-es évek parlamenti és kormányzati jogalkotásának erősen központosító jellegét, mint az új önkormányzati törvény 2011-ben, a szakigazgatási jogalkotás ${ }^{58}$ megyei és fővárosi kormányhivatalok, járási és fővárosi kerületi hivatalok feladatellátása, ${ }^{59}$ új közüzemi és közszolgáltatási modellek.

Vitatott kérdés a kormányzat és az önkormányzati szereplők között a járvány elleni védekezésben való részvétel és a költségekhez történő hozzájárulás. A védekezés elsődleges szintjét a kormányzati intézkedések jelentik - például járványvédelmi alap; munkahely- és gazdaságvédelmi akciótervek, vagy az úgynevezett Kurzarbeitrendelet. ${ }^{60}$ Ezt egészítik ki a települési önkormányzatok saját intézkedései a járvány elleni helyi egészségügyi és gazdasági védekezésben. A járványidőszak fontos közpolitikai természetű vitája önkormányzati olvasatban, hogy amíg a saját forrásaikból úgymond „rendkívüli erőfeszítéseket” tesznek (például önkéntesek toborzása, arcmaszk és egyéb egészségügyi eszközök beszerzése, lakossági tesztelések, rendkívüli krízis-

$56479 / 2020$. (XI. 3.) Korm. rendelet a veszélyhelyzet idején alkalmazandó további védelmi intézkedésekről.

57 A 2020. november 11-én hatályba lépett 2020. évi CIX. törvény a koronavírus-világjárvány második hulláma elleni védekezésről 90 napra biztosítja a veszélyhelyzet fenntartását.

58 Lásd bővebben Kristó Katalin: Jóléti állam elméletek és családpolitika. Kodifikáció és Közigazgatás, 3. (2014a), 2. 73-82; Kristó Katalin: Szociálpolitika, szociális jog. Budapest, Nemzeti Közszolgálati Egyetem, 2014b; Imre Miklós et al.: Közigazgatási szakvizsga. Gazdasági igazgatás. Budapest, Nemzeti Közszolgálati Egyetem, 2015.

59 Kristó Katalin: Az új területi államigazgatási rendszer. Budapest, Nemzeti Közszolgálati Egyetem, 2013.

60 105/2020. (IV. 10.) Korm. rendelet a veszélyhelyzet idején történő csökkentett munkaidős foglalkoztatásnak a Gazdaságvédelmi Akcióterv keretében történő támogatásáról. 
támogatások a munkájukat elvesztőknek), addig kénytelenek központi irányú elvonásokkal szembesülni. A nyilvánvaló feszültségek mellett az önkormányzatok jelentős számú „jó gyakorlatot” (best practices) valósítottak meg a járvány alatt. ${ }^{61}$ Ezek felértékelődnek válságidőszakban, a helyben alkalmazott hatásos feladatellátási, pénzügyifinanszírozási, szervezési-koordinációs megoldások alkalmasak a további adaptációra, erősítve az önkormányzatok közötti párbeszédet, együttmüködéseket.

Korábban már esett szó arról, hogy veszélyhelyzetben az önkormányzatok első emberei gyakorolhatják egy személyben a testületi hatásköröket a katasztrófavédelmi törvény alapján. A településeken ez kivételes közjogi eszközt és közpolitikai döntési lehetőséget teremtett a polgármesterek (a Fővárosi Önkormányzat esetében a föpolgármester) számára. Mivel a jogszabály nem részletezi a helyettesítés tartalmi kereteit, így a településvezetők korlátlan lehetőséggel rendelkeznek veszélyhelyzeti időszakban a települések irányítására. Hasonlóan a Kormány veszélyhelyzetben megalkotott bizonyos rendeleteihez, jó néhány polgármesteri döntésnél felmerült a morális alapú közpolitikai kétség, hogy adott intézkedés mögötti motiváció alapja valóban a válságmenedzselés volt-e - például rendkívüli jutalmazások polgármesterek, alpolgármesterek számára, belső egyeztetés nélküli alpolgármesteri kinevezések, polgármesteri döntések a testület által korábban vitatott beruházási ügyekben. Ezekre, akár mint „rossz gyakorlatokra” is tekinthet az elemző, amennyiben a döntések mögötti háttérmotiváció sokkal inkább irányul politikailag kényes, vitás ügyek gyors keresztülvitelére, kihasználva a testületek korlátozott müködését. A Kormány a második veszélyhelyzet időszakában külön kormányrendeletben szabályozta a polgármester mozgásterét (például a polgármester, alpolgármester tartós akadályoztatásának esetében követendő helyettesítési eljárásrend). ${ }^{62}$ A 2021 tavaszán felpörgetett oltási folyamatnak köszönhetően visszaesett koronavírus esetszámokból fakadó lazító jellegü kormányzati döntések részeként 2021. június 15-től visszaáll a települési önkormányzati képviselő-testületek, a fővárosi és megyei közgyủlések, illetve ezek bizottságainak önálló feladat- és hatáskörgyakorlása. ${ }^{63}$

A Kormány-önkormányzatok koordináció fontos szereplői az önkormányzati szövetségek, amelyek információs és konzultációs feladatot látnak el a két szektor között. A koordináció 1990 óta többé-kevésbé folyamatos, 2006 óta pedig rendezett

61 A koronavírus-járvány elleni hatékony önkormányzati védekezés, fellépés volt a 2020. évi TÖOSZ Legjobb Önkormányzati Gyakorlatok kiírás fő célterülete, amelyre egyaránt pályáztak fővárosi kerületi önkormányzatok, megyei jogú városok, valamint kisvárosi és községi önkormányzatok. Bővebben lásd a TÖOSZ által kiadott Önkormányzat címü újság 2020/4. számát Önkormányzat, 30. (2020), 4.

62 15/2021. (I. 22.) Korm. rendelet a veszélyhelyzet ideje alatt a polgármesteri feladatok ellátásának egyes kérdéseiről.

$63307 / 2021$. (VI. 5.) Korm. rendelet a katasztrófavédelemről és a hozzá kapcsolódó egyes törvények módosításáról szóló 2011. évi CXXVIII. törvény egyes rendelkezéseinek eltérő alkalmazásáról. 
formális keretek között ${ }^{64}$ zajlik. A tapasztalatok azonban azt mutatják, hogy a konzultáció - különösen kormányzati oldalról - sokszor inkább csak látszólagos, mintsem valódi partneri viszonyon alapul.

\section{A két krízis tapasztalatainak szintetizálása}

Tanulmányunkban a két globális méretü, exogén válság hatásait vizsgáltuk a hazai önkormányzati szektoron. Empirikus tény, hogy az átfogó krízisek közpolitikai válságmenedzselése során felértékelődik a központi kormányzat szerepe, döntési és beavatkozási felelőssége - ez megfigyelhető a 2008-2009-es pénzügyi és gazdasági világválságnál, valamint a 2020-as Covid-19-járvány tapasztalatainál. ${ }^{65}$ Ugyanakkor a kormányzati döntéshozatal mozgástere jelentős mértékben függ az alkotmányos, közjogi berendezkedéstől; a válság idején fennálló és alkalmazott jogrend általános vagy különleges jellegétől; a kormányzat törvényhozói hátországától, támogatásától. Vizsgálati dimenzió a helyi önkormányzatok feladat- és hatásköre, közjogi és gazdasági autonómiájuk, valamint a válságidőszakban a rendelkezésre álló objektív környezeti (gazdasági és társadalmi) tényezők, valamint a kormányzat és helyi önkormányzati szektor közötti koordináció. Fontos horizontális kérdés, hogy krízisidőszakban a kormányzati közpolitikai intézkedések milyen mértékben érintik az önkormányzati rendszert, negatív esetben a már meglévő nehézségek mellett megnyílnak-e további konfliktusok, akár teljes „konfliktuskonténerek”.

A közpolitikai változás és krízis (policy change, policy crisis) kezelése érdekében hozott beavatkozások, közpolitikai intézkedések hatással vannak a szakpolitikai struktúrák működési alapparamétereire - erről szól Peter Hall első-, másod- és harmadrendű közpolitikai változáselmélete. Az átfogó krízisek megbontják a közpolitika „békeidőben” megszokott inkrementális működését (!), mivel felbomlik a gazdasági, társadalmi és politikai alrendszerek egyensúlyi állapota, és belép az úgynevezett megszakított egyensúly közpolitikai elmélete.

Az alábbi táblázat dimenziók mentén szintetizálja a két vizsgált krízis helyi önkormányzatokat érintő hazai történéseit, alkalmazva a különböző közpolitikai változás- és válságelméleteket. A válságkezelés azonnali és rövid távú hatások értékelését a különböző rendszerek hosszú távú adaptációs képességének - esetünkben az önkormányzati reziliencia, rugalmas ellenálló képesség - vizsgálata következik remélhetőleg egy következő tanulmányban.

64 2006-2010 között a Kormány-Önkormányzatok Egyeztető Fóruma (KÖEF); 2010 után változó elnevezés alatt előbb az Önkormányzatok Nemzeti Egyeztető Fóruma (ÖNEF), majd az Önkormányzatok Nemzeti Egyeztető Tanácsa (ÖNET) néven.

65 OECD: The territorial impact of COVID-19: Managing the crisis across levels of government. Paris, (2020. november 10.). 
1. táblázat: Összehasonlító táblázat a 2008-as pénzügyi és gazdasági, valamint a 2020-2021-es koronavírus-járvány meghatározott dimenzióiról

\begin{tabular}{|c|c|c|}
\hline $\begin{array}{l}\text { Vizsgálati } \\
\text { dimenziók }\end{array}$ & $\begin{array}{l}\text { 2008-2009-es pénzügyi } \\
\text { és gazdasági válság }\end{array}$ & $\begin{array}{l}\text { 2020-2021-es } \\
\text { koronavírus-járvány }\end{array}$ \\
\hline $\begin{array}{l}\text { A válság rövid } \\
\text { távú (éven belüli) } \\
\text { makrogazdasági } \\
\text { hatásai }\end{array}$ & $\begin{array}{l}\text { 6\%-os GDP-arányos államadósság- } \\
\text { növekedés. } \\
\text { 6\%-os bruttó hazai termék csök- } \\
\text { kenés. } \\
\text { GDP-arányosan 4\%-ra csökkenő } \\
\text { költségvetési hiány. } \\
\text { Romló foglalkoztatási mutatók. }\end{array}$ & $\begin{array}{l}\text { 8\%-os GDP-arányos államadósság- } \\
\text { növekedés (2020. első - harmadik } \\
\text { negyedév). } \\
\text { 5,6\%-os bruttó hazai termék csökkenés. } \\
\text { Közel 10\%-ra duzzadó költségvetési } \\
\text { hiány fél év alatt. } \\
\text { Romló foglalkoztatási mutatók. }\end{array}$ \\
\hline $\begin{array}{l}\text { Politikai háttér, } \\
\text { parlamen- } \\
\text { ti viszonyok } \\
\text { és kormányzati } \\
\text { mozgástér }\end{array}$ & $\begin{array}{l}\text { Instabil parlamenti viszonyok. } \\
\text { Kisebbségi kormányzás. } \\
\text { Kormányválság, kormányváltás } \\
\text { (Bajnai-kabinet 2009-2010). } \\
\text { Rendkívül szűk kormányzati politi- } \\
\text { kai mozgástér. }\end{array}$ & $\begin{array}{l}\text { Alkotmányos (2/3-os) kormányzati } \\
\text { többségű parlament. } \\
\text { Fegyelmezett belső kormányzati viszo- } \\
\text { nyok és működés. } \\
\text { Széles kormányzati mozgástér. }\end{array}$ \\
\hline $\begin{array}{l}\text { Alkotmányos, } \\
\text { közjogi háttér }\end{array}$ & $\begin{array}{l}\text { Általános jogrend a válság idősza- } \\
\text { kában. } \\
\text { Parlamenti kisebbség a kormányzat } \\
\text { mögött (többségi, de széttöredezett } \\
\text { parlamenti ellenzék). } \\
\text { Széles települési önkormányzati } \\
\text { feladat- és hatásköri rendszer } \\
\text { (1990. évi LXV. törvény - Ötv.). }\end{array}$ & $\begin{array}{l}\text { Különleges jogrend (veszélyhelyzet) } \\
\text { alkalmazása. } \\
\text { Minősített alkotmányos parlamenti } \\
\text { többség a kormányzat mögött. } \\
\text { Szűkebb települési önkormányzati } \\
\text { feladat- és hatásköri rendszer (2011. évi } \\
\text { CLXXXIX. törvény - Mötv.). }\end{array}$ \\
\hline $\begin{array}{l}\text { A helyi ön- } \\
\text { kormányzati } \\
\text { szektort érintő } \\
\text { döntési keret- } \\
\text { rendszer a vál- } \\
\text { ságkezelés során }\end{array}$ & $\begin{array}{l}\text { Szűk parlamenti beavatkozási } \\
\text { lehetőség a kormányzat számá- } \\
\text { ra („feles” törvények elfogadása } \\
\text { csak külső parlamenti támogatás } \\
\text { mellett). } \\
\text { Önkormányzati normatívák alakí- } \\
\text { tása a költségvetési törvényben. } \\
\text { Kormány- és miniszteri rendeletek. } \\
\text { Zéró mozgástér 2/3-os törvényho- } \\
\text { zási tárgykörökben (Alkotmány; } \\
\text { Önkormányzati törvény stb.). } \\
\text { A helyi adók rendszere változat- } \\
\text { lan (1990. évi C. törvény a helyi } \\
\text { adókról). } \\
\text { Érintetlen forrásszabályozási } \\
\text { keretek. } \\
\text { Konfliktusokkal terhelt, de } \\
\text { alapvetően moderált koordináció } \\
\text { a Kormány és az önkormányzati } \\
\text { szektor között (KÖEF; szaktárcák). }\end{array}$ & $\begin{array}{l}\text { Széles parlamenti beavatkozási lehetö- } \\
\text { ség a kormányzat számára (Alaptörvény } \\
\text { és 2/3-os „sarkalatos” törvények; } \\
\text { „felhatalmazási” törvény; egészségügyi } \\
\text { válsághelyzet). } \\
\text { Közvetlen kormányzati beavatkozás } \\
\text { a helyi adók rendszerébe (gépjárműadó; } \\
\text { idegenforgalmi adó; helyi iparüzési adó). } \\
\text { Közvetlen kormányzati beavatkozás } \\
\text { az önkormányzati bevételek rendszeré- } \\
\text { be (díjtételek felfüggesztése veszélyhely- } \\
\text { zetben). } \\
\text { A veszélyhelyzet mint alkotmányos } \\
\text { és politikai „tesztüzem” a kormányzat } \\
\text { számára. } \\
\text { Teljes mértékben konfliktusokkal terhelt } \\
\text { viszony a Kormány és az önkormány- } \\
\text { zati szektor között (prompt intézke- } \\
\text { dések; kormánypárti önkormányza- } \\
\text { tok preferálása a koordináció során; } \\
\text { kifejezetten rossz Kormány - Fővárosi } \\
\text { Önkormányzat viszony). }\end{array}$ \\
\hline
\end{tabular}




\begin{tabular}{|c|c|c|}
\hline $\begin{array}{l}\text { Önkormányzati } \\
\text { reakciók a vál- } \\
\text { ságkezelés során }\end{array}$ & $\begin{array}{l}\text { Határozott, de moderált önkor- } \\
\text { mányzati oppozíció a parlamenti } \\
\text { és központi kormányzati megszorí- } \\
\text { tásokkal szemben. } \\
\text { Nem beszélhetünk önálló } \\
\text { Kormány-Budapest politikai } \\
\text { törésvonalról. } \\
\text { Jelentős mértékű helyi adóemelés } \\
\text { nem történik a válság alatt. } \\
\text { Az önkormányzati működés struk- } \\
\text { turális kerete nem változik (Ötv., } \\
\text { költségvetési törvény). } \\
\text { Nincsenek különleges jogkörök. }\end{array}$ & $\begin{array}{l}\text { Éles önkormányzati oppozíció a parla- } \\
\text { menti és központi kormányzati intézke- } \\
\text { désekkel szemben (különösen az ellen- } \\
\text { zéki Budapest és más városok alkotta } \\
\text { Szabad Városok Szövetsége részéről). } \\
\text { Van önálló Kormány-Budapest politikai } \\
\text { törésvonal. } \\
\text { Rendkívül beszűkülő önkormány- } \\
\text { zati bevételi lehetőségek (helyi adók } \\
\text { átcsoportosítása; helyi adómoratórium } \\
\text { a 2021. évre). } \\
\text { A polgármesterek különleges jogköre } \\
\text { a veszélyhelyzet időszakában (a Kat. } \\
\text { alapján). }\end{array}$ \\
\hline $\begin{array}{l}\text { A központi kor- } \\
\text { mányzati dönté- } \\
\text { sek új szakpoli- } \\
\text { tikai problémát, } \\
\text { „konfliktus- } \\
\text { konténert" } \\
\text { nyitnak meg }\end{array}$ & $\begin{array}{l}\text { A központi szintű forráskivonás } \\
\text { (főleg a bérpolitika területén) által } \\
\text { okozott működési nehézségek. } \\
\text { A forráskivonás ellenére az ön- } \\
\text { kormányzati forrásszabályozás } \\
\text { keretrendszere nem változott. } \\
\text { Nem nyílt meg új „konfliktus- } \\
\text { konténer”. }\end{array}$ & $\begin{array}{l}\text { A válságkezelés során hozott megszorí- } \\
\text { tó központi intézkedések (bevételkiesés) } \\
\text { által okozott múködési nehézségek. } \\
\text { Az önkormányzati bevételek rendszere } \\
\text { (helyi adók) alapvetően megváltozik. } \\
\text { Új „konfliktuskonténer” nyílt. }\end{array}$ \\
\hline $\begin{array}{l}\text { A kormányzati } \\
\text { szintü közpoli- } \\
\text { tikai változások } \\
\text { természete } \\
\text { és a krízis jellege } \\
\text { (Peter Hall) }\end{array}$ & \begin{tabular}{|l|} 
Másodrendű közpolitikai válto- \\
zás - a krízis hatására az önkor- \\
mányzati működés alapkeretei \\
és a korábban kitűzött kormányzati \\
közpolitikai célok (fiskális szigor; \\
önkormányzati együttműködések \\
preferálása) változatlanok marad- \\
nak, csak az eszközök megválasztá- \\
sában történik módosulás. \\
\end{tabular} & $\begin{array}{l}\text { Harmadrendű közpolitikai válto- } \\
\text { zás - a krízis hatására az önkormányzati } \\
\text { működés kereteit radikális beavatkozás } \\
\text { éri a központi szintről (veszélyhelyzet } \\
\text { mint különleges jogrend; megszorítások } \\
\text { a helyi adó területén; díjtételek ingye- } \\
\text { nessé tétele). }\end{array}$ \\
\hline $\begin{array}{l}\text { Közpolitikai } \\
\text { probléma- és krí- } \\
\text { zismenedzsment } \\
\text { (Lindblom, } \\
\text { Bouckaert } \\
\text { et al. })^{66}\end{array}$ & \begin{tabular}{|l|} 
A megszakított egyensúly jelensége \\
kevésbé jellemző - már a válság \\
elött (2006-2008) jellemzőek \\
az önkormányzati szektort érintő \\
megszorítások. \\
Alapvetően negatív, de moderált \\
közpolitikai visszacsatolás az ön- \\
kormányzati szektor részéről.
\end{tabular} & $\begin{array}{l}\text { Megszakított egyensúly elmélete na- } \\
\text { gyon jellemző - a válság előtt lezajlott } \\
\text { önkormányzati konszolidáció. } \\
\text { A központi kormányzati döntéshozatal } \\
\text { felértékelődése és a lokális önkormány- } \\
\text { zati pozíciók radikális leértékelődése } \\
\text { az úgynevezett koronacionalizmus } \\
\text { jelenségének a jegyében. } \\
\text { Egyértelműen negatív és radikálisan } \\
\text { elutasító közpolitikai visszacsatolás } \\
\text { az önkormányzati szektor részéről. }\end{array}$ \\
\hline
\end{tabular}

Forrás: a szerzők szerkesztése

66 Geert Bouckaert et. al.: European Coronationalism? A Hot Spot Governing a Pandemic Crisis. Public Administration Review, 80. (2020), 5. 765-773; Charles Lindblom: A kis lépések problémája. In Richard Stillman (szerk.): Közigazgatás. Budapest, Osiris-Századvég, 1994. 83-98. 


\section{Irodalomjegyzék}

Állami Számvevőszék: Vélemény a Magyar Köztársaság 2009. évi költségvetési javaslatáról (2009. szeptember). Online: www.asz.hu/storage/files/files/\%C3\%96sszes\%20jelent\%C3\%A9s/ 2009/0935j000.pdf?download=true

Állami Számvevőszék: Észrevétel a Magyar Köztársaság 2009. évi költségvetési törvényjavaslata javasolt módosításához (2008. november). Online: www.asz.hu/storage/files/files/\%C3\%96sszes\%20 jelent\%C3\%A9s/2008/0836mj000.pdf?download=true

Bouckaert, Geert - Davide Galli - Sabine Kuhlmann - Renate Reiter - Steven Van Hecke: European Coronationalism? A Hot Spot Governing a Pandemic Crisis. Public Administration Review, 80. (2020), 5. 765-773. Online: https://doi.org/10.1111/puar.13242

Bovens, Mark - Paul 't Hart - B. Guy Peters (szerk.): Success and Failure in Public Governance: A Comparative Analysis. Cheltenham, Edward Elgar, 2001a. Online: https://doi. org/10.4337/9781843762850

Bovens, Mark - Paul 't Hart - B. Guy Peters (szerk.): Analysing Governance Success and Failure in Six European States. In Mark Bovens - Paul 't Hart - B. Guy Peters (szerk.): Success and Failure in Public Governance: A Comparative Analysis. Cheltenham, Edward Elgar, 2001b. 12-26. Online: https://doi.org/10.4337/9781843762850.00010

Boyne, George A.: What is public sector improvement? Public Administration, 81. (2003), 2. 211-227. Online: https://doi.org/10.1111/1467-9299.00343

Boyne, George A.: Explaining Public Service Performance: Does Management Matter? Public Policy and Administration, 19. (2004), 4. 100-117. Online: https://doi.org/10.1177/095207670401900406

Capano, Giliberto - Michael Howlett - M. Ramesh: Bringing Governments Back in: Governance and Governing in Comparative Policy Analysis. Journal of Comparative Policy Analysis: Research and Practice, 17. (2015), 4. 311-321. Online: https://doi.org/10.1080/13876988.2015.1031977

Fisher, Frank: Reframing Public Policy: Discursive Politics and Deliberative Practices. Oxford, Oxford University Press, 2003. Online: https://doi.org/10.1093/019924264X.001.0001

Gupta, Dipak K.: Analyzing Public Policy: Concepts, Tools, E Techniques. Washington, DC, CQ Press, 2011.

Howlett, Michael: Designing Public Policies: Principles and Instruments. Abingdon, Routledge, 2010. Online: https://doi.org/10.4324/9780203838631

Imre Miklós - Mikó Zoltán - Lentner Csaba - Kristó Katalin - Kovács Éva Margit - Boros Anita:Közigazgatási szakvizsga. Gazdasági igazgatás. Budapest, Nemzeti Közszolgálati Egyetem, 2015. Online: http://m.ludita.uni-nke.hu/repozitorium/bitstream/handle/11410/10221/K\%c3\%b6zigazgat\% c3\%a1si\%20szakvizsga\%20Gazdas\%c3\%a1gi\%20igazgat\%c3\%a1s.pdf?sequence=1\&isAllowed=y

Kaiser Tamás (szerk.): A modern kormányzás koncepcionális és közpolitikai keretei. Hazai és nemzetközi dimenziók. Budapest, Dialóg Campus, 2019. Online: https://nkerepo.uni-nke.hu/xmlui/ bitstream/handle/123456789/12762/web_PDF_ATMA_Modern_kormanyzas.pdf?sequence=1

Körösényi András - Illés Gábor - Metz Rudolf: A politikai vezetők szerepe válsághelyzetekben. In Körösényi András (szerk.): Viharban kormányozni: Politikai vezetök válsághelyzetekben. Budapest, MTA TK PTI, 2017. 9-48. Online: https://core.ac.uk/download/pdf/148786679.pdf

Központi Statisztikai Hivatal: Makrogazdaság, 2008-2009. Budapest, (2010a). Online: www.ksh.hu/ docs/hun/xftp/idoszaki/makro/makrogazdasag0809.pdf

Központi Statisztikai Hivatal: A válság hatása a munkaeröpiacra. Budapest, (2010b. április). Online: www.ksh.hu/docs/hun/xftp/idoszaki/pdf/valsagmunkaeropiacra.pdf 
Kristó Katalin: Az új területi államigazgatási rendszer. Budapest, Nemzeti Közszolgálati Egyetem, 2013.

Kristó Katalin: Jóléti állam elméletek és családpolitika. Kodifikáció és Közigazgatás, 3. (2014a), 2. 73-82. Kristó Katalin: Szociálpolitika, szociális jog. Budapest, Nemzeti Közszolgálati Egyetem, 2014b.

Lindblom, Charles E.: The Science of "Muddling Through". Public Administration Review, 19. (1959), 2. 79-88. Online: https://doi.org/10.2307/973677

Lindblom, Charles E.: The Intelligence of Democracy. New York, Free Press, 1965.

McConnell, Allan: Policy Success, Policy Failure and Grey Areas In-Between. Journal of Public Policy, 30. (2010), 3. 345-362. Online: https://doi.org/10.1017/S0143814X10000152

McConnell, Allan: Understanding Policy Success: Rethinking Public Policy. Basingstoke, Palgrave Macmillan, 2010.

OECD: The territorial impact of COVID-19: Managing the crisis across levels of government. Paris, (2020. november 10.). Online: www.oecd.org/coronavirus/policy-responses/the-territorial-impact-of-covid-19-managing-the-crisis-across-levels-of-government-d3e314e1

Önkormányzat, 30. (2020), 4. Online: http://xn-tosz-5qa.hu/uploads/onkormanyzat-ujsag-pdf/ Onkormanyzat_2020_04_szam_OK\%20(1).pdf

Pawson, Ray: Evidence-based Policy: A Realist Perspective. London, Sage, 2006. Online: https://doi. org/10.4135/9781849209120

Pierson, Paul: Increasing Returns, Path Dependence, and the Study of Politics. American Political Review, 94. (2000), 2. 251-267. Online: https://doi.org/10.2307/2586011

Pierson, Paul: Politics in Time: History, Institutions, and Social Analysis. Princeton, Princeton University Press, 2004. Online: https://doi.org/10.1515/9781400841080

Stone, Deborah: Policy Paradox: The Art of Political Decision Making. New York, W.W. Norton, 2002.

Szabó Tamás: KÖEF a mérlegen: közpolitikai elemzés a Kormány-Önkormányzatok Egyeztető Fórum működéséről. Politikatudományi Szemle, 18. (2009), 3. 112-131. Online: http://real. mtak.hu/112204/1/szabo-2009-3.pdf

Szabó Tamás: A közpolitikai probléma. In Kaiser Tamás (szerk.): A modern kormányzás közpolitikai és koncepcionális keretei. Hazai és nemzetközi dimenziók. Budapest, Dialóg Campus, 2019. 105127. Online: https://nkerepo.uni-nke.hu/xmlui/bitstream/handle/123456789/12762/web_PDF_ ATMA_Modern_kormanyzas.pdf?sequence $=1$

Települési Önkormányzatok Országos Szövetsége: A TÖOSZ felmérésében résztvevő önkormányzatok több mint felének legfeljebb kéthónapnyi tartaléka van (2020. június 9.). Online: http:// xn-tosz-5qa.hu/uploads/dokumentumok-kiadvanyok/Onkorm_30_eve_konyv_netre.pdf

Ungvári Álmos - Hojnyák Dávid (2020): Az Európai Unió egyes tagállamainak koronavírus-járványra adott válasza, különös tekintettel a vizsgált államok által bevezetett különleges jogrendi szabályozásra. Miskolci Jogi Szemle, 15. (2020), 1. 122-138. Online: www.mjsz.uni-miskolc.hu/ files/10860/10_ungvarhojnyak_t\%C3\%B6rdelt.pdf

Weimer, David L. - Aidan R. Vining: Policy Analysis: Concepts and Practice. $5^{\text {th }}$ Edition, Upper Saddle River, NJ, Pearson, 2005.

Zongor Gábor: Új közigazgatási területi egység: a különleges gazdasági övezet. Új Magyar Közigazgatás, 13. (2020a), 3. 38-41.

Zongor Gábor: Önkormányzati érdekérvényesítés 1990-2020. In Gyergyák Ferenc (szerk.): A magyar önkormányzatok 30 éve. Tanulmányok, adatok, tények a helyi önkormányzatok három évtizedébőll. Budapest, Települési Önkormányzatok Országos Szövetsége, 2020b. 94-115. 